\title{
Pengembangan Assesmen Afektif Pembelajaran Berbasis Proyek Pada Mata Pelajaran Biologi Siswa SMA Negeri 2 Majene
}

\author{
Jirana $^{1)}$, Suradi Tahmir ${ }^{2)}$, Khalifah Mustami ${ }^{3)}$ \\ ${ }^{1}$ Program Studi Pendidikan Biologi Pascasarjana Universitas Negeri Malang \\ Prodi Pendidikan Biologi-FMIPA, Universitas Sulawesi Barat \\ ${ }^{2}$ FMIPA, Universitas Negeri Makassar \\ ${ }^{3}$ Saintek, Universitas Islam Negeri Alauddin Makassar \\ Email : jiran_taheer@yahoo.co.id
}

\begin{abstract}
Abstrak. Hasil belajar dipandang sebagai akibat proses belajar dan pencapaian hasil belajar lebih banyak ditentukan oleh proses pembelajaran. Penilaian bertujuan mengetahui hasil belajar siswa. Penelitian ini merupakan Penelitian pengembangan yang bertujuan untuk mengembangkan assesmen afektif siswa melalui pembelajaran berbasis proyek melalui model pembelajaran kooperatif tipe group Investigation. Subjek uji coba adalah siswa SMA Negeri 2 Majene kelas $X_{1}$ sebanyak 23 orang. Teknik pengumpulan data dilakukan dengan wawancara dan tes hasil belajar dalam bentuk essay. Teknik analisis data dengan menggunakan analisis statistik deskriptif. Analisis Validitas dengan Correlate Bivariate Pearson diperoleh nilai korelasi untuk setiap butir soal yang lebih besar dari 0,3 dengan nilai korelasi berdasarkan SPSS lebih kecil dari 0,05. Tingkat reliabilitas lebih besar 0,70 yaitu masing-masing $0,798,0,804$, dan 0,811. Melalui wawancara siswa berpendapat bahwa pembelajaran ini menyenangkan, hal ini menyebabkan nilai siswa pada setiap pertemuan meningkat.
\end{abstract}

Kata Kunci: Assesmen, Afektif, Pembelajaran Proyek

\begin{abstract}
Result of learning is perceived as effect of learnig process and achieving of learning res ult mostly depend on learning process. Scoring has purpose to know the student's result of learning. This study is developing study that has purpose to develop student affective assesmen through project based learning by cooperative investigation group type. The subject of study are 23 Student of SMA Negeri 2 Majene X-1 class . Collecting data technique by interviewing and assessing learning result in essay. Data analysis is using descriptive statistic analysis. Validity analysis is using Correlate Birariate Pearson. The result correlation score for each item of the testing is more than 0,3 with correlation score based on SPSS lower than 0,05 . Reliability level more than 0,70 those are 0,798 , 0,804 , and 0,811 from interview result, students opine that the process is enjoyable, this affected students score of each meeting increasing.
\end{abstract}

Keyword: Assessment, Afective, Project Based Learning 


\section{PENDAHULUAN}

Penilaian atau asssesmen mengandung arti mengambil keputusan terhadap sesuatu berdasar atau berpegang pada ukuran baik atau buruk, sehat atau sakit, pandai atau bodoh (Anas, 2011). Print (1983) mengatakan kegiatan evaluasi merupakan kegiatan akhir dari proses pengukuran dan penilaian sehingga diperoleh keputusan Anas (Anas, 2011). Mengukur adalah membandingkan sesuatu dengan satu ukuran. Pengukuran bersifat kuantitatif sedangkan menilai merupakan langkah untuk mengambil suatu keputusan terhadap sesuatu dengan ukuran baik buruk atau bersifat kualitatif Suharsimi (2012). Penilaian adalah suatu proses membandingkan suatu obyek atau gejala dengan mempergunakan patokan-patokan tertentu seperti baik tidak baik, memadai tidak memadai, memenuhi syarat tidak memenuhi syarat (Djaali dan Pudji, 2008). Penilaian adalah "it is essentially concerned with firstly making sense out of measurement data and and assigning a mark, a grade, a rank or some form of qualitative comment" (Prrint, 1993). Gambar 1. Hirark1 Kerja Assessment

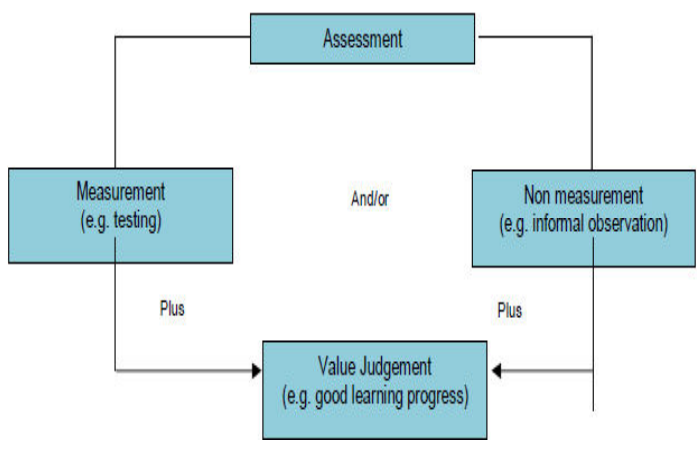

Apapun bentuk penilaian autentik yang dipakai khususnya mengembangkan sebuah proyek, para peserta didik mampu menunjukkan secara lengkap ruang lingkup pembelajaran mereka dan pada saat yang bersamaan dapat menambah pengetahuan dan keterampilan peserta didik. Assesmen autentik dapat juga menjadikan peserta didik lebih termotivasi dengan menghubungkan mata pelajaran akademik dengan dunia nyata dengan cara yang bermakna. Peserta didik tidak menghafalkan fakta tetapi menggunakan keahlian berfikir dalam tingkatan yang lebih tinggi untuk tujuan penting yang mempengaruhi konteks kehidupan mereka sehari-hari (Johnson, 2007).

Salah satu penilaian yang mutlak dilakukan dalam proses pembelajaran adalah penilaian afektif. Afektif merupakan karakteristik atau unsur afektif yang diukur, bisa berupa minat, sikap, motivasi, konsep diri, nilai, apresiasi, dan sebagainya. Dapat dilihat dari perkataan atau perbuatan yang dapat memunculkan perilaku positif, netral, atau negatif. Muslich (2010) menjelaskan bahwa penilaian terhadap aspek afektif dilakukan selama berlangsungnya kegiatan belajar mengajar baik di dalam maupun di luar kelas. Umumnya penilaian perilaku dilakukan guru selama ini hanya dengan memberikan prediksi atau perkiraan terhadap prilaku peserta didik. Guru mengalami kesulitan untuk memberikan kategori penilaian semacam ini karena mereka tidak memiliki kriteria untuk menetapkan kategori. Indikator yang menjadi alat ukur penilaian tentang aspek-aspek yang harus dinilai, sebagaian besar tidak dipahami oleh guru (Uno \&Koni, 2012).

Terdapat dua hal yang berhubungan dengan penilaian afektif yang harus dinilai. Pertama, kompetensi afektif yang ingin dicapai dalam pembelajaran meliputi tingkatan pemberian respons, apresiasi, penilaian dan internalisasi. Kedua, sikap dan minat peserta didik terhadap mata pelajaran dan proses pembelajaran. Dalam proses pembelajaran terdapat empat tipe karakteristik afektif yang penting yaitu sikap, minat, konsep diri dan nilai (Arifin, 2009). Menurut Popham 1995 dalam Mardapi (2004) bahwa ranah afektif menentukan keberhasilan seseorang. Orang yang tidak memiliki kemampuan afektif yang baik, sulit mencapai keberhasilan studi yang optimal. Hasil belajar kognitif dan psikomotorik akan optimal jika peserta didik mempunyai kemampuan afektif tinggi. Arikunto (2003) menjelaskan bahwa pengukuran ranah afektif tidak dapat dilakukan setiap saat (dalam arti pengukuran formal) karena perubahan tingkah laku siswa tidak dapat berubah sewaktu-waktu. Pengubahan sikap seseorang memerlukan waktu yang relatif lama.

Pengukuran ranah afektif pada pendidikan terdiri dari 5 hierarki ranah afektif yaitu (1) penerimaan atau receiving, (2) jawaban atau responding, (3) penilaian atau valuing, (4) organisasi atau arganization, dan (5) karakterisasi sebuah nilai atau seperangkat nilai atau characterization by a value or value complex (Kirkendall dkk, 1982, Krathwohl, $d k k$ (1997). Terdapat dua metode yang dapat digunakan untuk mengukur aspek afektif, yaitu metode observasi dan metode laporan diri. Penggunaan metode observasi berdasarkan pada asumsi bahwa karateristik afektif dapat dilihat dari perilaku atau 
perbuatan yang ditampilkan dan reaksi psikologi. Metode laporan diri berasumsi bahwa yang mengetahui keadaan afektif seseorang adalah dirinya sendiri. Namun hal ini menuntut kejujuran dalam mengungkap karakteristik afektif diri sendiri.

Penilaian merupakan salah satu pekerjaan yang sulit untuk dilakukan oleh seorang penilai termasuk guru, utamanya pada penilaian afektif sehingga fakta yang terjadi bahwa guru jarang melakukan penilaian pada aspek afektif. Penelitian pengembangan ini bertujuan untuk mengembangkan assesmen afektif siswa melalui pembelajaran berbasis proyek pada model pembelajaran kooperatif tipe group Investigation

\section{METODE}

Jenis penelitian yang akan dilakukan adalah penelitian pengembangan yang dilaksanakan di SMA Negeri 2 Majene. Sebjek uji coba adalah siswa kelas $\mathrm{X}_{1}$ semester genap dengan jumlah responden 23 SMA Negeri 2 Majene yang dibagi secara homogen ke dalam 6 kelompok dan diberikan tugas proyek yang sama. Teknik pengumpulan data pada aspek afektif yaitu dengan melakukan observasi langsung terhadap prilaku subjek uji coba secara menyeluruh pada tahapan pembelajaran berbasis proyek. Observasi prilaku dan kemampuan unjuk kerja dilakukan oleh 3 observer dengan menggunakan lembar observasi. Teknik analisis yang digunakan adalah analisis statistik deskriptif untuk mendeskripsikan data kuantitatif dan memberikan makna terhadap deskripsi data tentang isi. Data yang dianalisis adalah data hasil validasi instrumen penilaian autentik berbasis proyek aspek afektif. Analisis data yang diperoleh dikelompokkan menjadi tiga yaitu; (1) analisis validitas; (2) analisis reliabilitas; dan (3) analisis praktibilitas.

\section{HASIL DAN PEMBAHASAN}

\section{Hasil}

1) Validasi Rubrik Penilaian Afektif

Validasi rubrik penilaian afektif oleh validator sebagai berikut:

Tabel 4.3 Hasil Validasi Rubrik Penilaian Afektif Pengembangan assesmenAutenik Berbasis Proyek

\begin{tabular}{|c|c|c|c|}
\hline No & Aspek penilaian & $\bar{x}$ & Ket \\
\hline 1. & Aspek Petunjuk & 3,56 & Valid \\
\hline 2. & Aspek Bahasa & 3,67 & Valid \\
\hline 3. & Aspek Isi & 4,00 & Valid \\
\hline & Rata-rata & 3,77 & Valid \\
\hline
\end{tabular}

penilaian total

Berdasarkan tabel 4.3 hasil validasi

rubrik penilaian afektif sebagai berikut:

1. Nilai rata-rata validitas aspek petunjuk rubrik penilaian afektif adalah $\bar{x}=3,56$ dinyatakan dalam kategori "valid" $(3,5 \leq \bar{x} \leq 4,5)$

2. Nilai rata-rata validitas aspek bahasa rubrik penilaian afektif adalah $\bar{x}=3,67$ dinyatakan dalam kategori "valid" $(3,5 \leq \bar{x} \leq 4,5)$.

3. Nilai rata-rata validitas aspek isi rubrik penilaian afektif adalah $\bar{x}=4,00$ dinyatakan dalam kategori "valid" $(3,5 \leq \bar{x} \leq 4,5)$

Berdasarkan uraian hasil analisis diatas, nilai rata-rata total validitas rubrik penilaian afektif adalah $\bar{x}=3,77$ dari skor ideal 5 sesuai kriteria valid (Darwis dalam Arwiyani, 2010), nilai ini valid" $(3,5 \leq \bar{x} \leq$ 4,5). Jadi ditinjau keseluruhan aspek, maka instrumen penilaian afektif dinyatakan memenuhi kriteria valid.

\section{Pembahasan}

\section{1) Validasi instrumen penilaian afektif.}

Instrumen penilaian afektif yang telah dikembangkan divalidasi oleh ahli. Hasil validasi instrument penilaian afektif secara lengkap disajikan pada Lampiran Hal dan rincian hasil validasi secara ringkas disajikan dalam Tabel 4.6 sebagai berikut:

\begin{tabular}{clcc} 
Tabel & $\begin{array}{c}\text { 4.6 Hasil } \\
\text { Penilaian } \\
\text { Afektif }\end{array}$ & $\begin{array}{c}\text { Validasi } \\
\text { Pengembangan }\end{array}$ & \multicolumn{1}{c}{ instrumen } \\
& Assesmen Autentik Berbasis Proyek. \\
\hline No & Aspek penilaian & $\overline{\boldsymbol{x}}$ & Ket \\
\hline 1. & Substansi & 4,00 & Valid \\
2. & Konstruksi & 4,08 & Valid \\
3. & Bahasa & 4,17 & Valid \\
\hline \multicolumn{4}{c}{ Rata-rata } \\
& 4,08 & Valid \\
\hline
\end{tabular}

Berdasarkan tabel 4.6 Hasil Validasi Penilaian Afektif Pengembangan Perangkat Penilaian Assesmen Autentik Berbasis Proyek sebagai berikut:

1. Nilai rata-rata valid instrumen penilaian afektif untuk aspek substansi adalah $\bar{x}=4,00$ dinyatakan dalam kategori 'valid' $(3,5 \leq \bar{x} \leq 4,5)$

2. Nilai rata-rata valid instrumen penilaian afektif untuk aspek bahasa adalah $\bar{x}=4,08$ dinyatakan dalam kategori "valid" $(3,5 \leq \bar{x} \leq 4,5)$

3. Nilai rata-rata valid instrumen penilaian afektif untuk aspek isi adalah 
$\bar{x}=4,17$ dinyatakan dalam kategori ' valid" $(3,5 \leq \bar{x} \leq 4,5)$

Berdasarkan uraian hasil analisis diatas, nilai rata-rata total valid instrumen penilaian afektif adalah $\bar{x}=4,08$ dari skor ideal 5 sesuai kriteria valid (Darwis dalam Arwiyani, 2010), nilai ini valid" $(3,5 \leq \bar{x} \leq$ 4,5). Jadi ditinjau keseluruhan aspek, maka instrumen penilaian afektif dinyatakan memenuhi kriteria valid.

\section{PEMBAHASAN}

\section{1). Uji validitas penilaian afektif}

Berdasarkan hasil analisis valid terhadap instrumen penilaian afektif dengan menggunakan analisis Correlate Bivariate Pearson diperoleh nilai korelasi untuk setiap pertemuan 1, 2, dan 3 secara berturut-turut adalah 0,$910 ; 0,935$; dan 0,801 lebih besar dari 0,3 . Menurut kriteria Cronbach standar minimal koefisien korelasi sebagai acuan validiats adalah 0,30, maka seluruh nilai korelasi untuk pertemuan 1, 2 dan 3 valid.

Demikian juga jika digunakan acuan bahwa untuk signifikansi 0,05 yang digunakan, diperoleh bahwa untuk pertemuan 1,2 , dan 3 secara berturut-turut 0,$000 ; 0,000$ dan 0,002 lebih kecil dari 0,05 . Secara keseluruhan nilai signifikansi setiap pertemuan lebih kecil dari 0,05 sehingga dapat dikatakan bahwa penilaian afektif beberapa pertemuan valid secara keseluruhan.

\section{2). Uji koefisien reliabilitas Alpha Cronbach penilaian afektif}

Berdasarkan hasil analisis yang dilakukan dengan menggunakan SPSS, maka diperoleh hasil analisis untuk pengujian koefisien Alpha Cronbach pada penilaian afektif sebesar 0,858. Menurut Sudijino, suatu tes dikatakan memiliki tingkat reliabel yang tinggi apabila koefisien reliabelnya sama dengan atau lebih besar dari 0,70. Dari hasil SPSS koefisien korelasi penilaian afektif sebesar 0,858 lebih besar dari 0,70, maka dapat dikatakan bahwa penilaian afektif adalah reliabel.

Meskipun dalam Pelaksanaan uji perangkat assesmen hasil pengembangan terbilang berhasil, namun dalam mengaplikasikan hasil pengembangan ini memiliki beberapa kendala yaitu waktu yang digunakan sangat banyak sehingga harus mempunyai waktu-waktu tertentu dalam prooses pelaksanaannya, hal ini sesuai dengan teori yang dikemukakan oleh Sa'dijah (2009) bahwa salah satu kelemahan assesmen autentik adalah waktu pelaksanaan penilaian terbilang relatif lama. Selain itu penilaian yang dilakukan kurang relevan yang disebabkan rubrik penilaian yang dikembangkan sangat rumit dan banyak sehingga kemungkinan guru bersangkutan tidak dapat menilai dengan baik sesuai dengan teori yang dikemukakan oleh Sa'dijah (2009) bahwa terdapat kecendrungan guru bersikap subjektif dalam menilai sehingga dikhawatirkan penilaian kurang relevan.

\section{SIMPULAN DAN SARAN}

\section{Simpulan}

1. Valid yang dibuktikan dengan adanya koefisien korelasi dari perangkat penilaian kognitif, penilaian psikomotorik, dan penilaian afektif lebih besar dari 0,30 dan nilai signifikansi lebih kecil dari taraf signifikansi 5\%

2. Reliabel. Berdasarkan hasil uji reliabel secara empirik dengan menggunakan rumus Alpha Cronbach diperoleh nilai koefisien korelasi perangkat penilaian kognitif, penilaian psikomotorik, dan penilaian afektif secara keseluruhan lebih besar dari 0,70

\section{Saran}

Berdasarkan hasil yang diperoleh dari penelitian ini, beberapa saran yang dianggap perlu sebagai berikut;

1. Diharapkan kepada guru-guru biologi khususnya guru SMA Majene untuk menerapkan perangkat ini dalam lingkup sekolah.

2. Diharapkan kepada guru-guru biologi dan para calon peneliti agar dapat mengembangkan assesmen autentik pada materi-materi lain sehingga penilaian dapat dilakukan secara objektif.

\section{DAFTAR PUSTAKA}

Arifin, Z. 2009. Evaluasi Pembelajaran Prinsip Teknik. Prosedur. Bandung:

Remaja Rosdakarya

Arikunto, S. 2003. Dasar-Dasar Evaluasi Pendidikan. Jakarta: Bumi Aksara. 2012. Dasar-Dasar Evaluasi Pendidikan. Jakarta: Bumi Aksara. Arwiyani. 2010. Pengembangan Perangkat Pembelajaran Matematika Model Kooperatif Tipe STAD Pada Siswa Kelas 8 SMP Negeri 1 Bontolempangan Kecamatan Bontolempangan Kabupaten Gowa. 
Skripsi. Tidak Diterbitkan. Makassar:

FMIPA Universitas Negeri Makassar.

Djaali, dan Muljono, P. 2008. Pengukuran dalam Bidang Pendidikan. Jakarta: Grasindo.

Johnson, E, B. 2007. Contextual Teaching and Learning, Menjadikan Kegiatan BelajarMengajar Mengasyikkan dan Bermakna. Bandung: Mizan Learning Center (MLC).

Kirkendall, E. G. dan Johnson, R. (1987). Measurement and Evaluation for Physical Educatio Champaign, Illinois: Human Kinetics.

Krathwohl, David R Benjamin S Bloom. 1971. Taxonomy of Educational Objecives. New York: David Mckay Company.

Mardapi, D. 2004. Penyusunan Tes Hasil

Belajar. Yogyakarta: Program

Pascasarjana

Miller, M. David dkk. 2009. Measurement and

Assessement in

Teaching. New Jersey: Pearson

Education Inc. Universitas Negeri

Yogyakarta.

Muslich, M. 2010. Authentic Assessment: Penilaian Berbasis Kelas dan Kompetensi. Bandung: Refika Aditama.

Print, M. 1993. Curriculum Development and Design. Australia: Allen \& Unwin.

Sa'dijah C. 2009. Assesmen dalam Pembelajaran Matematika. Malang: FMIPA Universitas Malang.

Uno, H., \& Koni, S. 2012. Assesmen Pembelajaran. Jakarta: Bumi Aksara. 